OPEN ACCESS

Edited by: Michael Benedik,

Texas A\&M University, United States

Reviewed by:

Anil Ojha,

Wadsworth Center, United States

Kaori Sakamoto,

University of Georgia, United States

*Correspondence:

Carla C. C. R. de Carvalho ccarvalho@tecnico.ulisboa.pt;

ccarvalho@ist.utl.pt

${ }^{\dagger}$ Present address:

Cátia Pacífico,

Institute of Meat Hygiene, Meat

Technology and Food Science,

University of Veterinary Medicine,

Vienna, Austria;

Karl Landsteiner University of Health

Sciences, Krems an der Donau,

Austria

Specialty section:

This article was submitted to Microbiotechnology, Ecotoxicology and Bioremediation, a section of the journal Frontiers in Microbiology

Received: 02 February 2018 Accepted: 24 April 2018 Published: 15 May 2018

Citation:

Pacifico C, Fernandes $P$ and

de Carvalho CCCR (2018) Mycobacterial Response to Organic Solvents and Possible Implications on Cross-Resistance With Antimicrobial Agents. Front. Microbiol. 9:961 doi: 10.3389/fmicb.2018.00961

\section{Mycobacterial Response to Organic Solvents and Possible Implications on Cross-Resistance With Antimicrobial Agents}

\author{
Cátia Pacifico ${ }^{1 \dagger}$, Pedro Fernandes ${ }^{1,2}$ and Carla C. C. R. de Carvalho ${ }^{1 *}$ \\ 1 Institute for Bioengineering and Biosciences, Department of Bioengineering, Instituto Superior Técnico, Universidade de \\ Lisboa, Lisbon, Portugal, ${ }^{2}$ Faculty of Engineering, Universidade Lusófona, Lisbon, Portugal
}

Mycobacterium vaccae, a bacterium found in soil, has been receiving attention as adjuvant to antituberculosis treatment, vaccines and immunotherapies and even as antidepressant. This bacterium is also able to degrade several pollutants, including aromatic compounds. The increasing presence of organic solvents in the environment may lead to $M$. vaccae adapted populations. A possible relationship between solvent tolerance and decreased susceptibility to other types of chemicals, including antibiotics, may pose a problem during opportunistic infections. The present study thus aimed at assessing if solvent adapted cells presented higher tolerance to antibiotics and efflux pump inhibitors (EPIs). M. vaccae cells were able to thrive and grow in the presence of up 20\% (v/v) glycerol, 5\% (v/v) ethanol, 1\% (v/v) methyl tert-butyl ether (MTBE) and $0.1 \%(\mathrm{~V} / \mathrm{V})$ toluene. During adaptation to increasing concentration of ethanol and MTBE, the cells changed their fatty acid profile, zeta potential and morphology. Adapted cells acquired an improved tolerance toward the EPIs thioridazine and omeprazole, but became more susceptible to the antibiotics levofloxacin and teicoplanin when compared with non-adapted cells.

Keywords: Mycobacterium vaccae, tolerance, cell adaptation, membrane, antibiotic, efflux pump inhibitor

\section{INTRODUCTION}

Solvents are essential in several industries where they are used to dissolve solutes and as reaction media for low water soluble substrates and/or products. They are also widely used as degreasing and cleaning agents and in the formulation of paints, inks and adhesives, and sometimes end up reaching the environment. While some organic solvents such as hydrocarbons, aromatic compounds, alcohols and ketones are known pollutants, some of them have been considered as emerging pollutants. The latter include solvents used in pharmaceuticals, cosmetics and pesticides with effect on living organisms still unclear but with known endocrine disruption potential, and putative ecological and health effects. 
Bacteria exposed to toxic organic solvents developed an array of mechanisms to thrive, including extrusion of solvents through efflux pumps (Isken and de Bont, 1996; Ramos et al., 1998; de Carvalho et al., 2014), enzymatic modification of the toxic compound (Tay et al., 1998; de Carvalho and da Fonseca, 2005; Tyagi et al., 2011), morphological changes (de Carvalho et al., 2004a), vesicle formation (Ramos et al., 2002; Baumgarten et al., 2012), accumulation of storage lipids (Cortes and de Carvalho, 2015), adjustments in the fatty acid composition of cells (Heipieper and de Bont, 1994; de Carvalho et al., 2005a; Nielsen et al., 2005; Unell et al., 2007; de Carvalho, 2012), modification of phospholipid headgroups (Ramos et al., 2002), phospholipid content and biosynthesis rate (Pinkart and White, 1997). These mechanisms have been extensively reviewed for Gram-negative bacteria but studies regarding tolerance mechanisms in Grampositive bacteria have also been gaining interest.

Each bacterial strain possesses a certain level of tolerance toward organic solvents by genetic determination, although environmental factors may also play a role (Aono et al., 1994; Kobayashi et al., 1998). Some strains are even very efficient in degrading compounds that are regarded as toxic and lethal, such as toluene, by most bacterial cells (de Carvalho et al., 2007; Murínova and Dercová, 2014). The Corynebacteriaceae is the taxonomic family that harbors most Gram-positive bacteria with xenobiotic biodegradability capacity, including the highly efficient biodegraders Gordonia, Rhodococcus and Mycobacterium (Bell et al., 1988; Willumsen and Karlson, 1997; Arenskötter et al., 2004). M. vaccae, used in the present study, is known to metabolize, e.g., acetone, cyclohexane, styrene, benzene, ethylbenzene, propylbenzene, dioxane, and 1,2-dichloroethylene and to possess a co-oxidative capacity which results in the formation of intermediate molecules more amenable to mineralization than the initial recalcitrant compounds (Burback and Perry, 1993). This is an advantage regarding the inclusion of mycobacteria in bioremediation strategies or as biocatalysts in industrial processes. However, some nontuberculous mycobacteria are opportunistic pathogens and cause disease in humans and animals such as poultry and fish (Briancesco et al., 2013). Nevertheless, M. vaccae has been used as immunotherapeutic agent for tuberculosis treatment ( $\mathrm{Xu}$ et al., 2009; Yang et al., 2011).

Since organic solvents are ubiquitous environmental contaminants and are present in disinfecting solutions for health care facilities and household cleaning products, it is important to assess if their contact with mycobacterial communities can favor the appearance of tolerant strains toward other chemicals such as anti-mycobacterial drugs. The solvents used in the present study were selected due to their known occurrence in the environment as pollutants. Methyl tert-butyl ether (MTBE) and ethanol are commonly used as additives of gasoline, since they can enhance its fuel octane value, which resulted in their widespread release into the environment (Deeb et al., 2003; Manzetti and Andersen, 2015). Contamination of groundwater with MTBE is often accompanied by aromatic compounds such as toluene (Wang and Deshusses, 2007). Aromatic and polyaromatic hydrocarbons are persistent organic pollutants mainly released to the environment by the petroleum industry and during storage and transportation of petroleum based products (Varjani et al., 2017). Lately, contamination with glycerol has been observed since this compound is the main byproduct formed during the production of biodiesel (Lemos et al., 2013). Both ethanol and glycerol are also recommended by the World Health Organization for handrub formulations and are commonly used in disinfectants and cleaning solutions (Penna et al., 2001; WHO, 2010). The aim of this study was thus the following: (i) to determine the tolerance of $M$. vaccae to ethanol, glycerol, MTBE and toluene and to assess the modifications occurring at the level of the fatty acid composition of the phospholipids of the cellular membrane during cell adaptation to the listed solvents; (ii) to adapt $M$. vaccae cells to the presence of organic solvents and assess if solvent-adapted cells present higher tolerance toward anti-mycobacterial drugs when compared with non-adapted cells.

\section{MATERIALS AND METHODS}

\section{Microorganism and Growth Conditions}

Mycobacterium vaccae ATCC 15483 cells were grown in $100 \mathrm{~mL}$ Erlenmeyer flasks containing $20 \mathrm{~mL}$ of Mueller-Hinton (MH) broth supplemented with $0.1 \%$ Tween 80, in an Agitorb 200 incubator (Aralab) at $30^{\circ} \mathrm{C}$ and $200 \mathrm{rpm}$. Growth was monitored by optical density (OD) measurements at $600 \mathrm{~nm}$.

\section{Growth During Solvent Exposure}

To assess the effect of organic solvents in the growth of $M$. vaccae, the tested solvent was added, at different concentrations, to mid-exponential phase cultures (optical density at $600 \mathrm{~nm}$ of $1.0 \pm 0.2$ ) growing in $\mathrm{MH}$ medium. Each assay was done at least in duplicate. Growth inhibition was determined in relation to non-stressed cells by calculating the ratio between the maximum growth rate attained in the presence of the solvent and that of the control cells grown in the absence of solvents. Growth was monitored and maintained under the same conditions as previously mentioned. Assays were done in duplicate.

\section{Bacterial Adaptation to Solvents}

A stepwise strategy was adopted to adapt bacteria as suggested previously (de Carvalho et al., 2007). Briefly, M. vaccae cells were grown in $100 \mathrm{~mL}$ Erlenmeyer flasks containing $40 \mathrm{~mL}$ of $\mathrm{MH}$ media supplemented with $0.1 \%$ Tween 80 and, once the culture reached mid-exponential phase, pulses of MTBE (to reach 1\% $\mathrm{v} / \mathrm{v}$ ) or ethanol (to reach $5 \% \mathrm{v} / \mathrm{v}$ ) were added. Further additions of solvent were made to the cultures whenever they reached midexponential phase. Growth was monitored and maintained under the same conditions as previously mentioned. Assays were done in duplicate.

\section{Chemicals}

Mueller-Hinton broth was purchased from Sigma-Aldrich and Tween 80 from Merck-Schuchardt. The solvents used in this work were ethanol (>99.9\%) from Panreac, toluene (>99.5\%) from Riedel-de Häen, MTBE (>99.5\%) from Fluka Analytical, and glycerol solution (86-89\%) from Sigma-Aldrich. The antibiotics 
were levofloxacin and teicoplanin whilst the efflux pump inhibitors (EPIs) used were thioridazine and omeprazole, all from Sigma-Aldrich.

\section{Fatty Acid Composition}

To evaluate the changes induced by each solvent, samples of $1 \mathrm{~mL}$ of cell suspension were collected before and during solvent exposure. Samples were centrifuged at 10,000 rpm during $5 \mathrm{~min}$ in a $\mu$ SpeedFuge SFA13K from Savant Technologies, and the pellet was washed twice with mili-Q water. The cell fatty acids were simultaneously extracted from the cell pellet and methylated to fatty acid methyl esters (FAMEs) using the instant-FAME method from MIDI, Inc. The analysis were carried out in a gas chromatograph $6890 \mathrm{~N}$ from Agilent Technologies, equipped with a flame ionization detector and an automatic injector 7683B, using a $25 \mathrm{~m}$ long Agilent J\&W Ultra 2 capillary column. FAMEs were identified by the PLFAD1 method of Sherlock ${ }^{\circledR}$ software version 6.2 from MIDI, Inc. The saturation degree was defined as the ratio between the sum of the percentage of saturated fatty acids and the sum of the percentage of monounsaturated fatty acids (MUFAs) present in the cells.

\section{Zeta Potential}

Samples of $1 \mathrm{~mL}$ of cell suspension were collected before and during solvent exposure, washed three times with milli-Q water, and $40 \mu \mathrm{L}$ were suspended in $2 \mathrm{~mL}$ of a $10 \mathrm{mM} \mathrm{KNO}_{3}$ solution. The electrophoretic mobility of mycobacterial cells was determined in a Doppler electrophoretic light scattering analyzer (Zetasizer Nano ZS, Malvern Instruments Ltd.) at $25^{\circ} \mathrm{C}$, using a clear disposable zeta cell. The zeta potential was determined using the electrophoretic mobility as an indirect measure of cell surface charge, according to the method of Helmholtzvon Smoluchowski (Hiemenz and Rajagopalan, 1986). The zeta potential of the organic solvents was measured using a Glass "Dip" Cell, also from Malvern Instruments Ltd. Samples were prepared by adding $0.5 \mathrm{~mL}$ of solvent to $2 \mathrm{~mL}$ of milli-Q water. Measurements of water-miscible solvents were done by adding $40 \mu \mathrm{L}$ of the solution to $2 \mathrm{~mL}$ of $10 \mathrm{mM} \mathrm{KNO}_{3}$. For waterimmiscible solvents, where a second phase was formed, $1 \mathrm{~mL}$ of the aqueous phase was retrieved after centrifugation and added to $2 \mathrm{~mL}$ of mili-Q water. An aliquot of $40 \mu \mathrm{L}$ of the mixture was collected and added to $2 \mathrm{~mL}$ of $10 \mathrm{mM} \mathrm{KNO}_{3}$. Calculations were performed using the Zetasizer software 7.10, from Malvern Instruments, Ltd. Assays were carried out at least in duplicate.

\section{Minimum Inhibitory Concentration Determination}

The minimum inhibitory concentration (MIC) was determined for antibiotics and EPIs by the broth microdilution method in 96-well microtitre plates (Sarstedt Inc.) according to CLSI (2014). Antibiotics and EPIs were serially diluted in twofold steps, in $150 \mu \mathrm{L}$ of $\mathrm{MH}$ broth, starting with the following initial concentrations: levofloxacin (10 and $7.5 \mu \mathrm{g} / \mathrm{mL}$ ), teicoplanin (100 and $75 \mu \mathrm{g} / \mathrm{mL}$ ), thioridazine (149.3 and $125 \mu \mathrm{g} / \mathrm{mL}$ ) and omeprazole (500 and $400 \mu \mathrm{g} / \mathrm{mL}$ ). To each well, $50 \mu \mathrm{L}$ of cell suspension collected in the exponential phase and diluted in $\mathrm{MH}$ broth to reach a $0.5 \mathrm{McF}$ arland standard was added. The plate was covered with a Breathe-Easy ${ }^{\mathrm{TM}}$ sealing membrane (SigmaAldrich), and incubated at $30^{\circ} \mathrm{C}$. OD was measured at $600 \mathrm{~nm}$ after ca. $72 \mathrm{~h}$, at a wavelength of $600 \mathrm{~nm}$, in a spectrophotometer SpectraMax ${ }^{\circledR} 340$ PC from Molecular Devices. The experiments were performed in duplicate, both for solvent-adapted and nonadapted cells.

\section{Fluorescence Microscopy}

Cell viability and morphology were determined using a LIVE/DEAD ${ }^{\circledR}$ BacLight ${ }^{\mathrm{TM}}$ Bacterial Viability Kit from Molecular Probes (Invitrogen, Thermo Fisher Scientific). The cells were observed using an Olympus CX40 microscope equipped with an Olympus U-RFL-T burner and a U-MWB mirror cube unit (excitation filter: BP450-480; barrier filter: BA515). Images were collected with an Evolution ${ }^{\mathrm{TM}}$ MP 5.1 CCD color camera using the acquisition software Image-Pro Plus, both from Media Cybernetics. Cell viability was calculated by image analysis using Visilog 5 (Noesis SA) as previously described (de Carvalho et al., 2003).

\section{RESULTS}

\section{Growth of M. vaccae Cells Exposed to Organic Solvents}

Some bacteria are tolerant to organic solvents, being able to grow in their presence. $M$. vaccae was able to grow in the presence of glycerol, ethanol, toluene, and MTBE, but the growth rate was highly affected (Figure 1). The growth rate decreased to a third of that observed in the absence of an organic solvent in the presence of $20 \%(\mathrm{v} / \mathrm{v})$ glycerol, $3 \%$ ethanol, $1 \%$ MTBE and $0.1 \%$ toluene (Figure 1B). In all solvents, and particularly when water immiscible toluene and MTBE were used, a dose-dependent decrease in the growth rate was observed.

Mycobacterium vaccae cells were strongly inhibited by toluene and no growth was observed at $0.5 \%(\mathrm{v} / \mathrm{v})$ toluene. This is in accordance with previous observations, since toluene concentrations as low as $0.1 \%(\mathrm{v} / \mathrm{v})$ are usually sufficient to kill most microorganisms (de Carvalho et al., 2007). Nevertheless, the $M$. vaccae used in the present study was able to grow at toluene concentrations of 0.1\%. M. vaccae ATCC 29678 (JOB-5) and $M$. cosmeticum byf- 4 have been found to grow only in the presence of $0.01 \%$ toluene as sole carbon source (Burback and Perry, 1993; Zhang et al., 2013).

Although $M$. vaccae cells were strongly affected by the concentration of MTBE, visible by a sharp decrease in the growth rate with increasing MTBE concentrations, at 2.5\% (v/v) the cells still grew at $7.4 \%$ of the growth rate of unchallenged cells (Figure 1). There are few reports of bacteria able to use MTBE as sole carbon source, including Mycobacterium austroafricanum IFP 2012 (François et al., 2002) and M. austroafricanum IFP 2015 (Ferreira et al., 2005). While the former was isolated from activated sludge of a waste water treatment plant (without a known contact with MTBE), the latter was isolated from the drain-water of a storage tank containing MTBE-supplemented 


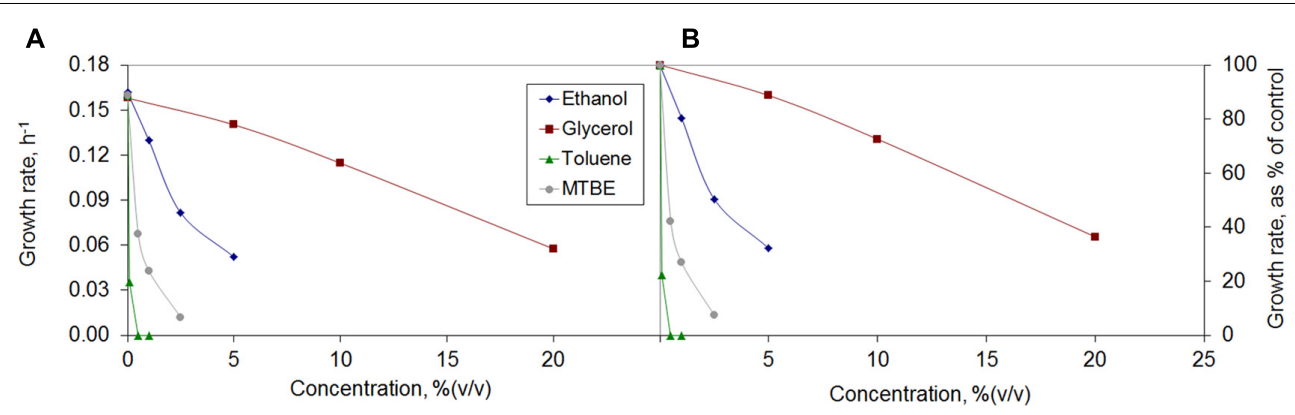

FIGURE 1 | Growth rates of Mycobacterium vaccae cells attained (A) and growth inhibition observed relative to control (B) during exposure to the organic solvents ethanol, glycerol, toluene, and methyl tert-butyl ether (MTBE).

gasoline. The M. vaccae ATCC 15483 used in the present study was isolated from dairy products from cow's milk (Bonicke and Juhasz, 1964), where low amounts of MTBE are frequently found (Hiatt and Pia, 2004).

Higher concentrations of ethanol and glycerol than toluene or MTBE were tolerated by M. vaccae cells (Figure 1). These cells also grew must faster in the presence of ethanol and glycerol, reaching ca. $0.05 \mathrm{~h}^{-1}$ at $5 \%$ ethanol and $20 \%$ glycerol which is ca. one-third of the growth rate attained by unchallenged cells (Figure 1). Glycerol is generally used as carbon source to grow Mycobacterium tuberculosis and, since no glycerol uptake system is known, it has been considered that the rate of glycerol intake by passive diffusion may be sufficient for cell growth as the generation time for M. tuberculosis is $24 \mathrm{~h}$ (Niederweis, 2008). Although, in the present study, M. vaccae cells preferred the carbon sources present in Mueller Hinton broth and decreased the growth rate with increasing glycerol concentrations, glycerol is oxidized and assimilated by several Mycobacterium species, including Mycobacterium smegmatis and Mycobacterium butyricum (Hunter, 1953).

\section{Solvent Regulation of Membrane Fatty Acid Composition}

The cells responded to the presence of organic solvents by making changes in the fatty acid content of the cellular membrane (Figure 2). The amount of solvent added decreased $M$. vaccae growth rate as mentioned in Section "Growth of $M$. vaccae cells exposed to organic solvents", but at least $87 \%$ of the cells in the cultures represented in each data point of Figure 1 were viable (data not shown), indicating that the large majority of the population adapted to the presence of the organic compounds at the concentrations tested.

When mid-exponentially growing cells were exposed to ethanol, the cells presented a lower degree of saturation of the fatty acids than unchallenged cells during the following $9 \mathrm{~h}$. However, the degree of saturation increased with incubation time for ethanol exposed cells. This was mainly the result of an increase in the amount of 16:0 ( $<37 \%$ increase) and 17:0 (up to 3.5-fold) and a significant decrease in the amount of $14: 1 \omega 9 \mathrm{c}$ (decrease

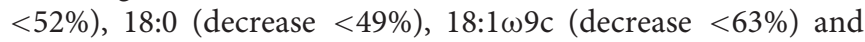
20:0 (up to $100 \%$ ). Cells exposed to toluene also presented a fatty acid profile with a lower degree of saturation than unchallenged cells at all tested time points (Figure 2). The degree of saturation of the fatty acids increased with time for all tested concentrations but the largest increase observed (for 1\% toluene) was only ca. $14 \%$. Cells exposed to toluene did not produce $16: 1 \omega 6 \mathrm{c}$ and maintained the content of $16: 0$ at ca. $17 \%$ and of $18: 1 \omega 9 \mathrm{c}$ at ca. $61 \%$. However, the content of 18:0 10-methyl increased 3.8-, 2.6-, $1.1-$, and 1.0-fold during the $11 \mathrm{~h}$ of exposure when the cells were exposed to $0,0.1,0.5$, and $1 \%$, respectively. A contrary effect was observed in Rhodococcus opacus strains where the content of 10 -methyl branched fatty acids increased up to $34 \%$ when the cells were exposed to toluene, in comparison to cells grown in fructose (Tsitko et al., 1999). The largest increase was observed in the amount of 18:0 10-methyl, which occurred at the expense of unsaturated and not saturated fatty acids. Since the degree of saturation of toluene exposed cells only slightly increased, $M$. vaccae may prefer to decrease the content of branched fatty acids to decrease membrane fluidity.

An increase in the content of the branched fatty acid 18:0 10-methyl was observed with time in M. vaccae cells exposed to glycerol and MTBE, but the values attained were lower than the attained for non-exposed cells (Figure 2). Not only glycerol exposed cells presented a degree of saturation higher than nonexposed cells along time, but cells exposed to glycerol increased in general 2.9-fold the content of 18:0 10-methyl (as mentioned, a 3.8-fold increase was observed in unchallenged cells along time). MTBE exposed cells presented, in general, a lower degree of saturation than non-exposed cells along time, but its value increased 32-79\% with exposure time, whilst a 4.4-, 3.7-, and 3.3-fold increase was observed in the amount of 18:0 10-methyl in cells exposed to $0.5,1$, and $2.5 \%$ MTBE, respectively. During exposure to both MTBE and glycerol, the cells responded by increasing the content of branched fatty acids with concomitant decrease in the content of MUFAs.

The synthesis of $16: 1 \omega 6 \mathrm{c}$ seems to be highly affected by the presence of organic solvents in M. vaccae (Figure 2). This fatty acid could be produced in cells exposed to all concentrations of ethanol and glycerol, reaching 7.6-9.2\% of the lipid content of the cells. However, it could only be synthesized in cells exposed up to $1 \%$ MTBE and was not produced in the presence of toluene. The production of $16: 1 \omega 6 \mathrm{c}$, which is relatively rare in nature, also decreased in Rhodococcus sp. 33 exposed to benzene 

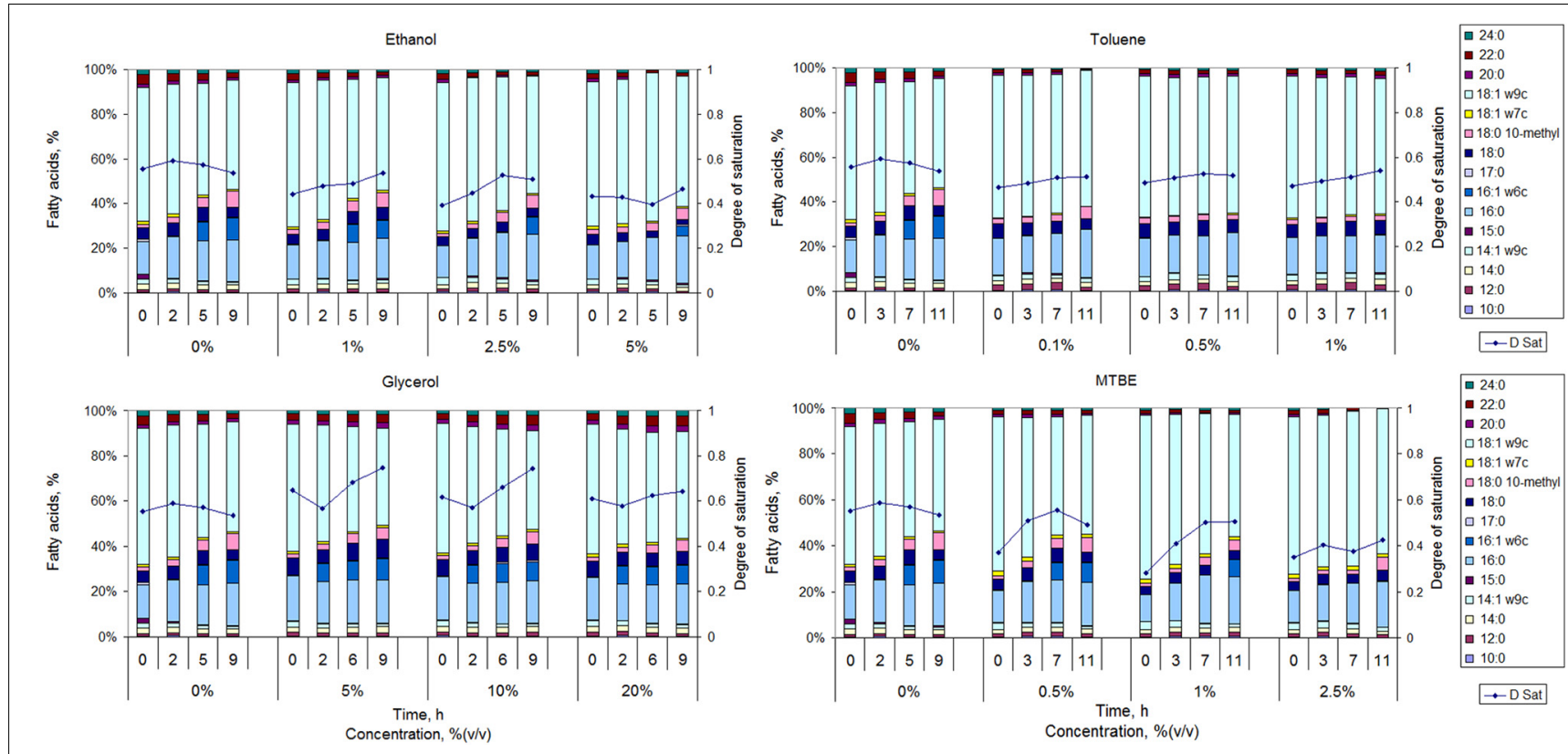

FIGURE 2 | Fatty acid composition and respective calculated degree of saturation (D Sat) of $M$. vaccae cells grown in the absence of organic solvents and in the presence of ethanol, glycerol toluene, and MTBE.

(Gutiérrez et al., 1999) and increased in Mycobacterium phlei grown at $10^{\circ} \mathrm{C}$ when compared to those grown at $35^{\circ} \mathrm{C}$ (Suutari and Laakso, 1993), suggesting its contribution to the adequate fluidity of the cellular membrane.

\section{Cell Adaptation to High Concentrations of Solvents}

To assess if $M$. vaccae cells adapted to organic solvents presented a higher tolerance to antibacterial drugs, cells were adapted to increasing concentrations of ethanol and MTBE throughout a period of approximately $70 \mathrm{~h}$. These solvents were used due to their relevance in the environment as they are widely used, e.g., as gasoline additives. MTBE is capable of raising the octane number and is extensively used in free-lead gasoline. However, the water solubility of MTBE, its high mobility in the environment and low biodegradability, has led to a widespread contamination of groundwater and soil (Bonjar, 2005; Abbaspour et al., 2013). The encouragement for the use of ethanol as gasoline additive and as biofuel, made by several governments, also increased the number of ethanol-based fuel spills and environmental contamination with repercussions on microbial communities (Nelson et al., 2010; Leal et al., 2017). The ability of Mycobacterium strains to degrade such compounds and their presence in contaminated soil (Johnson et al., 2004, Johnsen et al., 2007; Ohkubo et al., 2009) justifies the assessment of the adaptation of $M$. vaccae to these compounds.

To adapt $M$. vaccae to both ethanol and MTBE, a fedbatch approach was used, as previously demonstrated for the adaptation of Rhodococcus erythropolis cells to terpenes and toluene (de Carvalho et al., 2005b, 2007). Since M. vaccae cells were able to thrive under concentrations of $5 \%(\mathrm{v} / \mathrm{v})$ ethanol and $1 \%(\mathrm{v} / \mathrm{v})$ MTBE, several pulses of solvent were added to the cultures whenever mid-exponential phase was reached. Briefly, the first pulse of solvent was applied after $16 \mathrm{~h}$, when the cells were in the mid-exponential phase. Since more substrate was added, after an initial adaptation period, the cell cultures grew exponentially and another pulse of organic solvent was added. In total, three pulses of $5 \%(\mathrm{v} / \mathrm{v})$ ethanol and four pulses of $1 \%(\mathrm{v} / \mathrm{v})$ MTBE were added during the ca. $70 \mathrm{~h}$.

\section{Cell Morphology and Viability}

After $45 \mathrm{~h}$ of growth under each condition, the cell viability and morphology was assessed using fluorescence microscopy. Viability of cells exposed to ethanol was higher (94.2\%) than cells exposed to MTBE (48.8\%). Cell aggregation was extensive in the presence of both solvents (Figure 3). Cell aggregation is influenced by the hydrophobicity as well as by the electrokinetic potential of the cell surface and substrate (Borrego et al., 2000). Cells in the presence of ethanol were 3.7\% larger than those grown in the presence of MTBE, and presented a circularity value $12 \%$ higher. In the presence of MTBE, the cells were more elongated, but the difference in the area-to-volume ratio was only $2 \%$ if the cells are considered a prolate spheroid. However, cells exposed to ethanol and MTBE showed an area-to-volume ratio, respectively, 26.3 and $24.8 \%$ smaller than non-exposed cells. This suggests that the cells diminished their surface area to decrease exposure to the toxic environment.

\section{Net Surface Charge}

The surface charge of bacteria is associated to the composition of the cell envelope and the interactions of the cell with ions, particles and surfaces. This physicochemical property can affect the entry of metabolites and toxic compounds into the cells 

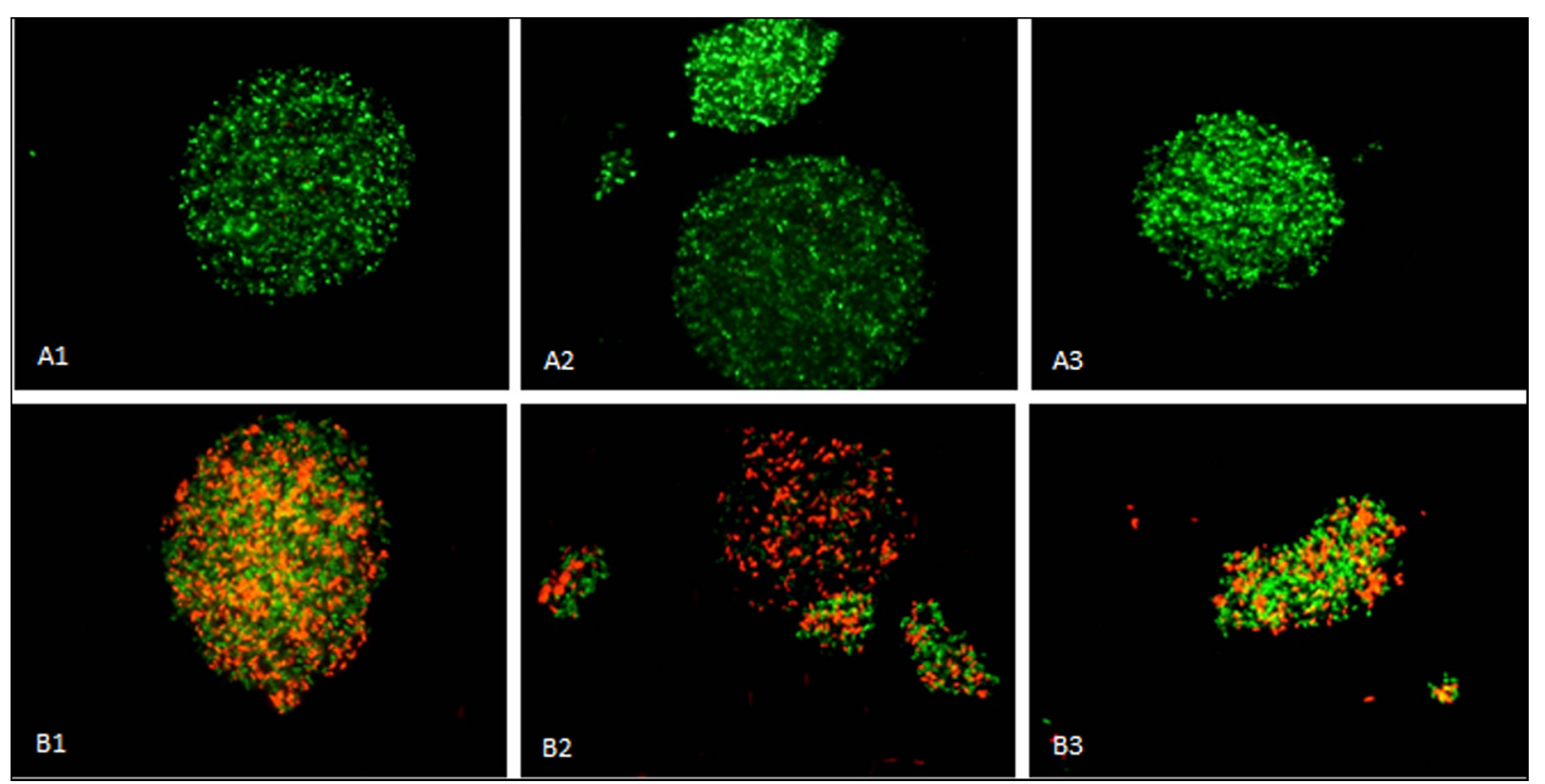

FIGURE 3 | Mycobacterium vaccae cells grown in the presence of ethanol (A1-A3) and MTBE (B1-B3) presented extensive aggregation with the formation of clusters. Images 1-3 are from independent samples taken at $45 \mathrm{~h}$ of cultivation. Viable cells are stained green by Syto ${ }^{\circledR} 9$ whilst non-viable cells are stained red by propidium iodide. Horizontal field width: $800 \mu \mathrm{m}$; vertical field width: $600 \mu \mathrm{m}$.

and bacteria-host interactions (Yeung and Grinstein, 2007; Raut et al., 2015; Malanovic and Lohner, 2016). Under physiological conditions, bacterial cells have negative surface charges but cells may change their charge in response to the growth conditions. $R$. erythropolis cells have been found to even become positive when grown in long-chain alkanes (de Carvalho et al., 2009).

Mycobacterium vaccae cells grown on MTBE presented a less negative character than cells grown on ethanol at all data points (Figure 4). After the third ethanol addition, the cells presented a zeta potential of $-48.4 \pm 0.2 \mathrm{mV}$, which is only $1.9 \%$ higher than the net surface charge presented by cells before exposure

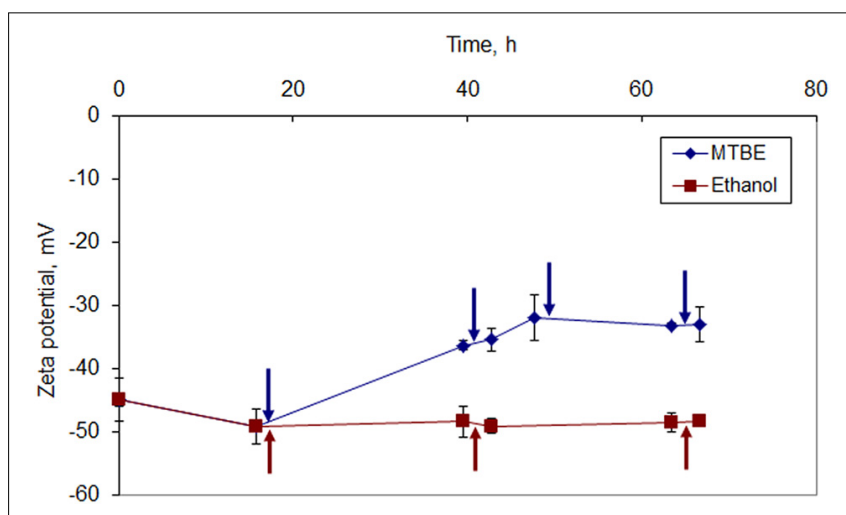

FIGURE 4 | Zeta potential of $M$. vaccae cells during growth in the presence of ethanol and MTBE. The first addition of solvent was done to reach an initial concentration of ethanol of $1 \%(\mathrm{v} / \mathrm{v})$ and $5 \%(\mathrm{v} / \mathrm{v})$ MTBE. The same respective amount was added at the times indicated by arrows. to the solvent. On the other hand, after the third and fourth MTBE additions, $M$. vaccae cells presented an almost constant zeta potential around $-33 \mathrm{mV}$, which is $44.6 \%$ less negative than that presented by cells prior to MTBE exposure.

Since the zeta potential is a measure of the electrostatic attraction/repulsion between particles, by decreasing the zeta potential values, cells growing in the presence of MTBE decreased the repulsion between themselves. This should have favored the observed cell aggregation. Cells grown in the presence of ethanol, where cell clustering was also considerable, apparently did not required adjustments in the net surface charge values.

\section{Fatty Acid Composition}

During growth in increasing organic solvent concentrations, $M$. vaccae cells adapted their lipid composition. However, cells presented a fatty acid composition dependent on the solvent (Figure 5). Cells grown in the presence of MTBE, increased the amount of branched saturated fatty acids (BSFAs) with MTBE additions from $0.4 \%$ after the 1 st to $42.0 \%$ after the 4 th addition. This occurred with concomitant decrease in the amount of MUFAs from 73.9 to $34.5 \%$. The main fatty acids involved were

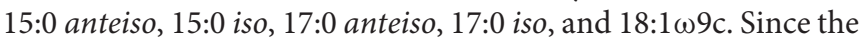
amount of saturated straight fatty acids (SSFAs) was maintained between $22.9-20.9 \%$, the degree of saturation of the cells during MTBE adaptation nearly doubled at the expenses of the decrease observed in the content of MUFA.

During adaptation of $M$. vaccae cells to ethanol, the production of BSFA was, however, very limited, reaching only $0.8 \%$ of the lipid content after the 3 rd ethanol addition (Figure 5). In this case, the most important changes observed after the 3rd ethanol addition were a $17.1 \%$ decrease in the content of MUFA 

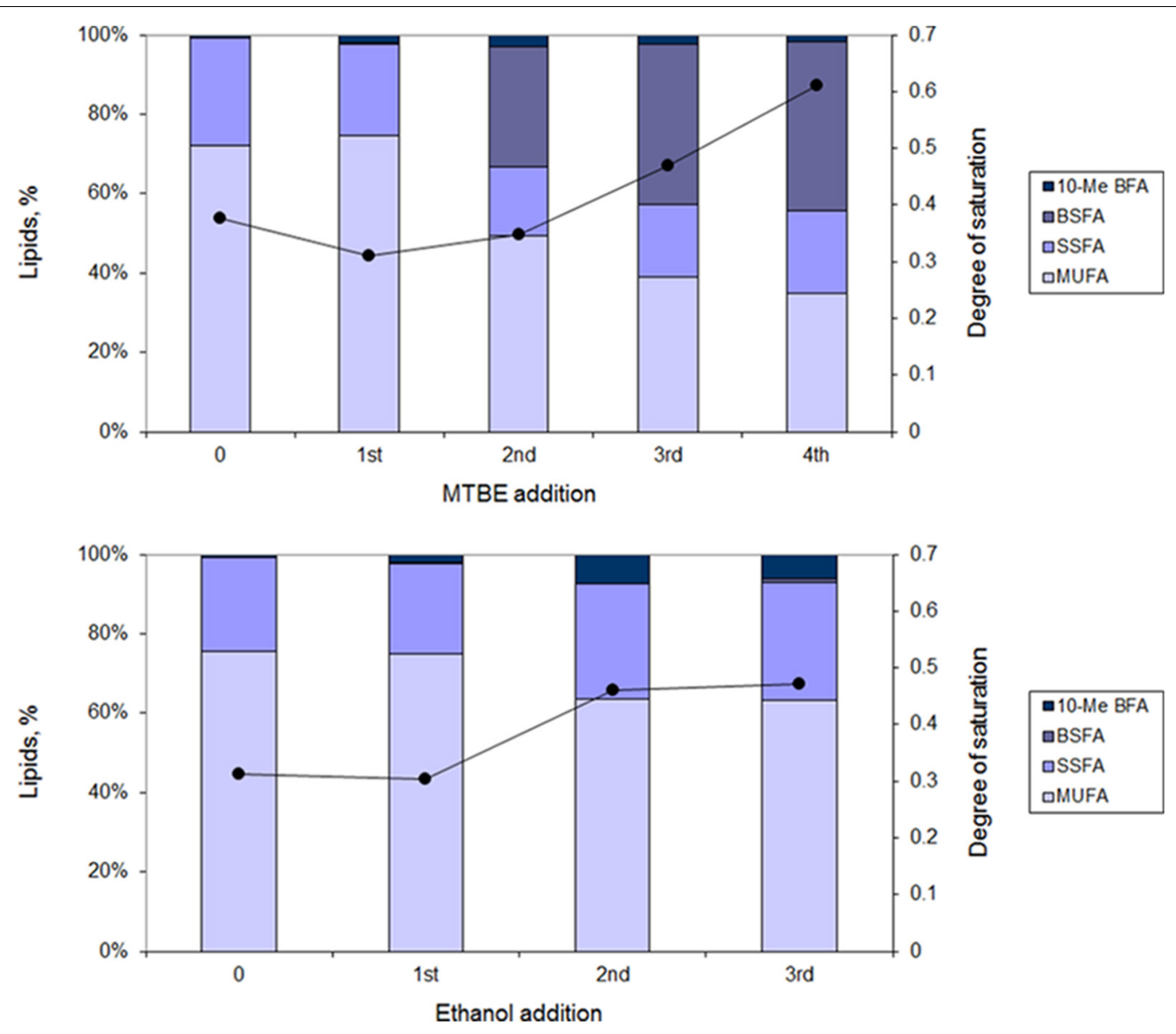

FIGURE 5 | Lipid composition (bars) and degree of saturation (line) of fatty acids of M. vaccae cells during adaptation to MTBE (Upper) and ethanol (Lower). The lipid composition was measured $1 \mathrm{~h}$ following addition of the organic solvent. MUFAs, monounsaturated fatty acids; SSFAs, saturated straight fatty acids; BSFAs, branched saturated fatty acids; 10-Me BFA, 10-methyl branched fatty acids.

and an increase of $24.5 \%$ in the amount of SSFA along time. An increase in the content of 10-methyl branched fatty acids (10-me BFA) up to $6 \%$ of the total lipids was also attained after the final pulse of ethanol.

\section{Tolerance of Solvent Adapted Cells to Antibiotics and Efflux Pump Inhibitors}

The MIC for the antibiotics teicoplanin and levofloxacin, and for the EPIs thioridazine and omeprazole, were determined for both non-adapted and solvent-adapted cells by the broth microdilution method. Solvent-adapted cells were shown to be more susceptible to teicoplanin than non-adapted cells: MTBEadapted cells endured half the concentration whilst ethanoladapted cells only grew in less than $25 \%$ of the concentration tolerated by non-adapted cells (Table 1). The MICs obtained for levofloxacin showed that both MTBE-adapted and nonadapted cells could grow up to a concentration of $0.6 \mu \mathrm{g} / \mathrm{mL}$, whilst ethanol-adapted cells could only thrive in the presence of $0.04 \mu \mathrm{g} / \mathrm{mL}$ of levofloxacin. $M$. vaccae cells adapted to both solvents presented a fourfold increase in the thioridazine MIC value and a twofold increase in the MIC of omeprazole, when compared to the MIC of non-adapted cells.
Cells adapted to ethanol and MTBE were grown in the presence of $1 / 2$ MIC of antibiotics/EPIs and solvent to further assess the changes occurring at the lipid level in the presence of multistresses. While cells adapted to ethanol increased the content of MUFA when grown in the presence of $1 / 2 \mathrm{MIC}$ of teicoplanin, cells grown in the presence of levofloxacin presented a lipid composition similar to cells adapted to ethanol but not exposed to antibiotics (Figure 6). The same was observed when

TABLE 1 | Minimum inhibitory concentration (MIC) of the antibiotics teicoplanin and levofloxacin and of the efflux pump inhibitors (EPIs) thioridazine and omeprazole toward $M$. vaccae cells not adapted to organic solvents and adapted to MTBE and ethanol.

\begin{tabular}{lccc}
\hline & \multicolumn{3}{c}{ MIC $(\mu \mathrm{g} / \mathbf{m L})$} \\
\cline { 2 - 4 } & $\begin{array}{c}\text { Non-adapted } \\
\text { cells }\end{array}$ & $\begin{array}{c}\text { MTBE-adapted } \\
\text { cells }\end{array}$ & $\begin{array}{c}\text { Ethanol-adapted } \\
\text { cells }\end{array}$ \\
\hline Teicoplanin & $>100$ & 50 & 25 \\
Levofloxacin & 0.6 & 0.6 & 0.04 \\
Thioridazine & 18.7 & 74.6 & 74.6 \\
Omeprazole & 250 & 500 & 500
\end{tabular}


the same cells were grown in the presence of $1 / 2$ MIC of the EPI thioridazine. However, ethanol adapted cells grown with $1 / 2$ MIC of omeprazole decreased the amount of SSFA with concomitant production of BSFA. These fatty acids were produced in high amount in MTBE adapted cells, as previously mentioned, and their content was further increased $30 \%$ in cells exposed to $1 / 2$ MIC of levofloxacin (Figure 6). On the other had, the amount of BSFA decreased on average $19.6 \%$ on MTBE adapted cells exposed to teicoplanin, thioridazine and omeprazole, while increasing $30.6 \%$ in cells exposed to levofloxacin. A general decrease was observed in the content of MUFA in cells exposed to both antibiotics and efflux pumps inhibitors, when compared to those not exposed, which was accompanied by a twofold increase in the amount of SSFA.

Regarding the degree of saturation of the fatty acids of the cells, those adapted to ethanol only changed this parameter in the presence of teicoplain: the degree of saturation decreased from 0.6 in non-exposed cells to 0.4 in cells exposed to the antibiotic (data not shown). However, M. vaccae cells adapted to MTBE changed the degree of saturation of their fatty acids considerably: cells exposed to the EPIs increased this parameter twofold whilst cells exposed to the antibiotics increased the degree of saturation at least threefold (data not shown). The MTBE-exposed cells thus required a decrease in the fluidity of the membrane to cope with the extra challenge.

\section{DISCUSSION}

The environmental $M$. vaccae, which is considered to grow rapidly in comparison to other species of the genus Mycobacterium, has been receiving important attention as several studies have shown important exposure related health benefits. As probiotic, ingestion of $M$. vaccae was found to decrease anxiety and improve learning in mice (Matthews and Jenks, 2013). Recent tests in rats immunized with heat killed $M$. vaccae preparation also suggest the potential of immunoregulatory strategies to prevent stress- and traumarelated psychiatric disorders (Fox et al., 2017). It has been

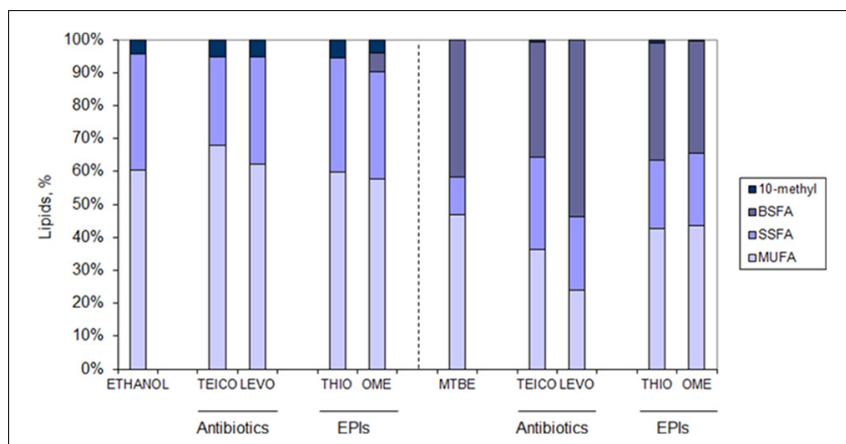

FIGURE 6 | Lipid composition of $M$. vaccae cells adapted to ethanol (Left) and MTBE (Right) and exposed to $1 / 2$ MIC of the antibiotics teicoplanin (TEICO) and levofloxacin (LEVO) and to $1 / 2$ MIC of the efflux pump inhibitors (EPIs) thioridazine (THIO) and omeprazole (OME) after $41 \mathrm{~h}$ of cell growth (mid-exponential phase). Fatty acid class abbreviation as in Figure $\mathbf{5}$. found that heat-killed $M$. vaccae may be useful as adjunctive to antituberculosis chemotherapy by clinical trials in newly diagnosed pulmonary tuberculosis human patients (Johnson et al., 2000), and as adjuvant for vaccines and immunotherapies (Skinner et al., 2001; Huang and Hsieh, 2017). Besides, a randomized phase III study showed that killed $M$. vaccae cells significantly improved the quality of live, by increasing cognitive functioning and vitality, of advanced lung cancer patients without affecting their overall survival time (O’Brien et al., 2004).

Although regarded as non-pathogen, $M$. vaccae has been associated to pulmonary and skin infections (Hachem et al., 1996; Katoch, 2004). M. vaccae may be found in the environment, and human contact with this species may be facilitated during outdoor activities and through agricultural products, but also by water distribution systems (Falkinham, 2009). The remarkable solute-stress tolerance of mycobacteria has been linked to their environmental tenacity (Santos et al., 2015). However, the major contribution for the ecology and epidemiology of nontuberculous mycobacteria is the effectiveness of hydrophobic cell envelope, which acts as a permeability barrier, containing mycolic acids arranged predominantly in a direction perpendicular to the cell wall surface (Nikaido et al., 1993; Hoffmann et al., 2008). Although the exact composition of the mycobacterial cell envelop is still being studied, most recent models propose an outermost layer, a cell wall and a conventional plasma membrane (Daffé et al., 2017; Rodriguez-Rivera et al., 2017). The latter is mainly composed by phospholipids such as cardiolipin, phosphatidylethanolamine, phosphatidylinositol, and glycosylated phosphatidylinositols (Crellin et al., 2013; Chiaradia et al., 2017). The particular lipid composition of mycobacteria has been related to resistance to disinfectants and antibiotics.

It has been suggested that environmental conditions may influence bacterial susceptibility to antimicrobials by promoting stress responses that result in altered gene expression patterns and cell physiology (Fernandes et al., 2003; Poole, 2012). The aim of the present study was thus to assess if cells exposed and adapted to the presence of organic solvents presented higher tolerance to antimicrobial agents than those non-adapted, and the role of lipids to this adaptation.

The growth rate of M. vaccae ATCC 15483 decreased to a third of that observed in the absence of an organic solvent in the presence of $20 \%(\mathrm{v} / \mathrm{v})$ glycerol, $3 \%$ ethanol, $1 \% \mathrm{MTBE}$, and $0.1 \%$ toluene. The most hydrophobic solvents tested thus caused highest bacterial growth inhibition. MTBE is a widely used gasoline additive often found in contaminated soil and water due to fuel leakage from storage tanks and during transportation. Toluene can enter cellular membranes and in Gram-negative bacteria it has been shown that it causes a transition from a lamellar bilayer state to a hexagonal state, resulting in removal of lipids and proteins from the membrane and changes in membrane potential (Heipieper et al., 1994; Sikkema et al., 1995). In the Gram-positive Staphylococcus haemolyticus, no significant changes in phospholipids abundance or distribution was observed in cells grown with and without toluene, but the cells changed significantly their fatty acid profile (Nielsen et al., 2005). Curiously, S. haemolyticus increased 
membrane fluidity when exposed to toluene, contrarily to common gram-negative bacteria which make the cytoplasmic membrane less fluid. $R$. erythropolis DCL14 also increased the amount of branched fatty acids while decreasing in $40 \%$ the content of straight-chain fatty acids (de Carvalho et al., 2007). In the case of $M$. vaccae, the cells increased the degree of saturation of their fatty acids with exposure time to all organic solvents tested, but while the value was lower than that presented by non-exposed cells when they were exposed to ethanol, MTBE and toluene, cells exposed to glycerol presented a higher degree of saturation than non-exposed cells. Jarlier and Nikaido (1990) calculated the permeability of $M$. chelonei to glycerol and found that the $K_{M}$ of the overall transport of glycerol to be $200 \mu \mathrm{M}$, suggesting a low permeability of the cell envelop to this small molecule. The low concentration of glycerol thus permitted in the interior of the cells may explain the high concentration of glycerol tolerated by $M$. vaccae cells in the environment.

When $M$. vaccae cells were allowed to adapt to increasing concentrations of ethanol and MTBE, by adding solvent pulses during cultivation, the cells apparently responded by decreasing membrane fluidity as result of a significant decrease in the amount of MUFAs. This resulted in an increase in the degree of saturation of the fatty acids with the amount of solvent added. However, the cells exposed to ethanol produced larger amounts of 10-methyl 18:0 (up to $6.1 \%$ of total lipids), whilst MTBE adapted cells increased the content of methyl branched fatty acids up to $42 \%$ of total lipids, particularly those iso branched. Poger et al. (2014) showed that fatty acid branching led to increased membrane fluidity since branches increased the area per lipid, reduced the bilayer thickness, lowered chain ordering, and led to the formation of kinks at the branching point. The results of the present study suggest that, during adaptation to both ethanol and MTBE, $M$. vaccae cells thus produced the fatty acids required to maintain the fluidity level necessary for cell survival and growth.

The alterations occurring at the lipid level were accompanied by changes in the zeta potential of $M$. vaccae cells which considerably decreased the negative character of their surface during adaptation to increasing concentrations of MTBE. This could explain the extensive cell aggregation observed in adapted M. vaccae cultures. However, cells adapted to ethanol, where aggregation was also extensive, did not change their zeta potential during adaptation. The aggregation was also favored by an area-to-volume ratio of solvent exposed cells smaller than that observed for non-exposed cells. Formation of large clusters of cells had been also observed during Mycobacterium sp. NRRL B-3805 exposure to both miscible and immiscible organic solvents, allowing protection of part of the cells from direct exposure to toxic molecules (de Carvalho et al., 2004b).

Cells adapted to organic solvents presented lower tolerance to teicoplanin and levofloxacin than non-adapted cells, although MTBE-adapted cells could endure higher concentration of both antibiotics than ethanol adapted cells. This could be the result of the changes in the fatty acid profile that MTBE-adapted cells carried out in the presence of the antibiotics, which resulted in a threefold increase of the degree of saturation. The glycopeptide teicoplanin affects peptidoglycan biosynthesis by binding to the D-Ala-D-Ala terminus of the pentapeptide side chains of peptidoglycan precursors, thus preventing polymerization reactions (Parenti, 1986). Teicoplanin is able to cross membranes due to the hydrophobicity of the molecule since the acyl substitute of the $N$-acylglucosamine is a fatty acid containing $10-$ 11 carbon atoms (Parenti, 1986), which apparently anchors the antibiotic to the bacterial membrane (Westwell et al., 1995). This was considered the reason why teicoplanin induced more changes in the lipid profile of Staphylococcus aureus cells than vancomycin (Gonçalves and de Carvalho, 2016). Keiser et al. showed the organization of peptidoglycan synthesis into networks with varying drug susceptibility in M. tuberculosis (Kieser et al., 2015). The mutants produced presented different susceptibility to drugs affecting the synthesis of cell-wall components but not to the detergent sodium dodecyl sulfate. This suggested that cell-wall synthesis and not altered bacterial permeability was responsible for the altered drug susceptibility. This is in accordance to the results observed in the present study.

Levofloxacin which is emerging as promising antibiotic against rapidly growing mycobacteria (Pang et al., 2015), is a fluoroquinolone antibiotic presenting a zwitterionic and an uncharged neutral form but both cross membranes via passive transport (Cramariuc et al., 2012). The neutral form easily permeates through a lipid bilayer, whilst the zwitterionic molecules form stacks with reduced polarity which favor their entrance into the bilayer (Cramariuc et al., 2012). Fluoroquinolones are becoming selected drugs for the treatment of multi-drug resistant tuberculosis, in particular levofloxacin due to its broad spectrum and activity against $M$. tuberculosis (Alvarez et al., 2014). However, when Sarathy et al. (2013) analyzed the accumulation of fluoroquinolones in nutrientstarved M. tuberculosis, they observed a marked loss of bactericidal activity in starved cells in comparison with growing cells. One of the reasons pointed out by the authors was the altered cellular permeability.

Mycobacterium vaccae cells adapted to both MTBE and ethanol also adjusted their fatty acid profile in the presence of the EPIs thioridazine and omeprazole. These compounds help to increase the activity of antibiotics by inhibiting the efflux pumps responsible for their removal, which results in a decrease of the MIC of the antibiotic when the inhibitor is present (Coelho et al., 2015). Thioridazine has been presented as an effective therapy for the treatment of pulmonary tuberculosis regardless of the antibiotic resistance phenotype of the M. tuberculosis strain (Amaral and Viveiros, 2017). Thioridazine was also suggested for the treatment of Mycobacterium avium complex (MAC) infections. The number of chronic infections caused by MAC are surpassing tuberculosis in the United States (Deshpande et al., 2016). The proton pump inhibitor omeprazole is effective in several eukaryotic and prokaryotic cells (da Silva et al., 2011) and it also presents antibacterial effects against several bacterial strains including Helicobacter pylori (Jonkers et al., 1996). However, it has been suggested that omeprazole may promote the growth of $M$. tuberculosis and MAC bacteria due to a high prevalence of infections caused by these bacteria in patients using acid-suppressive agents (Suzuki et al., 2000; Hsu et al., 2014). 
It has been shown that long-term exposure of $M$. tuberculosis to thioridazine increased the cell-envelope permeability (de Keijzer et al., 2016). However, MTBE adapted M. vaccae cells were able, apparently, to counteract this effect since a twofold increase in the degree of saturation was observed. Although the changes observed in ethanol adapted cells during growth in $1 / 2$ MIC of both EPIs were not as remarkable as those observed in MTBE adapted cells, in both cases adapted cells presented significantly higher MIC values in comparison to non-adapted cells. Since efflux pumps should be able to pump antibiotics and organic solvents (Fernandes et al., 2003; de Carvalho et al., 2014; Blanco et al., 2016), our results suggest that adaptation to MTBE and ethanol not only involved adaptations at the lipid level but also the number and/or activity of the efflux pumps. Further studies involving different classes of solvents, antibiotics and efflux pumps are required for the fully understanding of how bacterial exposure to disinfectants and pollutants might influence the efficacy of antibacterial compounds. The recent attention that $M$. vaccae has been receiving as adjuvant for tuberculosis treatment,

\section{REFERENCES}

Abbaspour, M., Javid, A. H., Yengjeh, R. J., Hassani, A. H., and Mostafavi, P. G. (2013). The biodegradation of methyl tert-butyl ether (MTBE) by indigenous Bacillus cereus strain RJ1 isolated from soil. Pet. Sci. Technol. 31, 1835-1841. doi: 10.1080/10916466.2011.611562

Alvarez, N., Zapata, E., Mejía, G. I., Realpe, T., Araque, P., Peláez, C., et al. (2014). The structural modeling of the interaction between levofloxacin and the Mycobacterium tuberculosis gyrase catalytic site sheds light on the mechanisms of fluoroquinolones resistant tuberculosis in Colombian clinical isolates. Biomed Res. Int. 2014:367268. doi: 10.1155/2014/367268

Amaral, L., and Viveiros, M. (2017). Thioridazine: a non-antibiotic drug highly effective, in combination with first line anti-tuberculosis drugs, against any form of antibiotic resistance of Mycobacterium tuberculosis due to its multi-mechanisms of action. Antibiotics 6:3. doi: 10.3390/antibiotics60 10003

Aono, R., Kobayashi, H., Joblin, K. N., and Horikoshi, K. (1994). Effects of organic solvents on growth of Escherichia coli K-12. Biosci. Biotechnol. Biochem. 58, 2009-2014. doi: 10.1271/bbb.58.2009

Arenskötter, M., Bröker, D., and Steinbüchel, A. (2004). Biology of the metabolically diverse genus Gordonia. Appl. Environ. Microbiol. 70, 3195-3204. doi: 10.1128/aem.70.6.3195-3204.2004

Baumgarten, T., Sperling, S., Seifert, J., von Bergen, M., Steiniger, F., Wick, L. Y., et al. (2012). Membrane vesicle formation as a multiple-stress response mechanism enhances Pseudomonas putida DOT-T1E cell surface hydrophobicity and biofilm formation. Appl. Environ. Microbiol. 78, 62176224. doi: 10.1128/aem.01525-12

Bell, K. S., Philp, J. C., Aw, D. W., and Christofi, N. (1988). The genus Rhodococcus. J. Appl. Microbiol. 85, 195-210. doi: 10.1046/j.1365-2672.1998.00525.x

Blanco, P., Hernando-Amado, S., Reales-Calderon, J. A., Corona, F., Lira, F., Alcalde-Rico, M., et al. (2016). Bacterial multidrug efflux pumps: much more than antibiotic resistance determinants. Microorganisms 4:14. doi: 10.3390/ microorganisms 4010014

Bonicke, R., and Juhasz, S. E. (1964). Beschreibung der neuen species Mycobacterium vaccae n. sp. Zentralbl. Bakteriol. Parasitenkd. Infektionskr. Hyg. $192,133-135$.

Bonjar, G. H. S. (2005). Biological activity of methyl tert-butyl ether in relation to soil microorganisms has a negative environmental impact. Am. J. Environ. Sci. 1, 106-109. doi: 10.3844/ajessp.2005.106.109

Borrego, S., Niubó, E., Ancheta, O., and Espinosa, M. E. (2000). Study of the microbial aggregation in Mycobacterium using image analysis and electron microscopy. Tissue Cell 32, 494-500. doi: 10.1054/tice.2000.0139 vaccines and immunotherapies makes this study relevant. Nevertheless, it should be also interesting to assess if exposure of $M$. tuberculosis to solvents also influences antituberculosis treatment.

\section{AUTHOR CONTRIBUTIONS}

CdC designed the experiments and wrote the manuscript. CP performed the experiments. CP and CdC analyzed the data. PF discussed the results and reviewed the manuscript.

\section{ACKNOWLEDGMENTS}

The authors acknowledge Fundação para a Ciência e a Tecnologia, I.P. (FCT), Portugal, for financial support through program "Investigador FCT 2013" awarded to CdC and project IF/01203/2013/CP1163/CT0002; the study was also partially supported by project UID/BIO/04565/2013.

Briancesco, R., Semproni, M., Paradiso, R., and Bonadonna, L. (2013). Nontuberculous mycobacteria: an emerging risk in engineered environmental habitats. Ann. Microbiol. 64, 735-740. doi: 10.1007/s13213-013-0708-8

Burback, B. L., and Perry, J. J. (1993). Biodegradation and biotransformation of groundwater pollutant mixtures by Mycobacterium vaccae. Appl. Environ. Microbiol. 59, 1025-1029.

Chiaradia, L., Lefebvre, C., Parra, J., Marcoux, J., Burlet-Schiltz, O., Etienne, G., et al. (2017). Dissecting the mycobacterial cell envelope and defining the composition of the native mycomembrane. Sci. Rep. 7:12807. doi: 10.1038/ s41598-017-12718-4

CLSI (2014). Performance Standards for Antimicrobial Susceptibility Testing; Twenty-Fourth Informational Supplement. Wayne, PA: Clinical and Laboratory Standards Institute.

Coelho, T., Machado, D., Couto, I., Maschmann, R., Ramos, D., von Groll, A., et al. (2015). Enhancement of antibiotic activity by efflux inhibitors against multidrug resistant Mycobacterium tuberculosis clinical isolates from Brazil. Front. Microbiol. 6:330. doi: 10.3389/fmicb.2015.00330

Cortes, M. A. L. R. M., and de Carvalho, C. C. C. R. (2015). Effect of carbon sources on lipid accumulation in Rhodococcus cells. Biochem. Eng. J. 94, 100-105. doi: 10.1016/j.bej.2014.11.017

Cramariuc, O., Rog, T., Javanainen, M., Monticelli, L., Polishchuk, A. V., and Vattulainen, I. (2012). Mechanism for translocation of fluoroquinolones across lipid membranes. Biochim. Biophys. Acta Biomembr. 1818, 2563-2571. doi: 10.1016/j.bbamem.2012.05.027

Crellin, P. K., Luo, C.-Y., and Morita, Y. S. (2013). "Metabolism of plasma membrane lipids in Mycobacteria and Corynebacteria," in Lipid Metabolism, ed. R. V. Baez (Rijeka: InTech).

da Silva, P. E., Von Groll, A., Martin, A., and Palomino, J. C. (2011). Efflux as a mechanism for drug resistance in Mycobacterium tuberculosis. FEMS Immunol. Med. Microbiol. 63, 1-9. doi: 10.1111/j.1574-695X.2011.00831.x

Daffé, M., Quémard, A., and Marrakchi, H. (2017). "Mycolic acids: from chemistry to biology," in Biogenesis of Fatty Acids, Lipids and Membranes, ed. O. Geiger (Cham: Springer International Publishing), 1-36.

de Carvalho, C. C. C. R., Costa, S., Fernandes, P., Couto, I., and Viveiros, M. (2014). Membrane transport systems and the biodegradation potential and pathogenicity of genus Rhodococcus. Front. Physiol. 5:133. doi: 10.3389/fphys. 2014.00133

de Carvalho, C. C. C. R., Cruz, A., Angelova, B., Fernandes, P., Pons, M. N., Pinheiro, H. M., et al. (2004a). Behaviour of Mycobacterium sp NRRL B3805 whole cells in aqueous, organic-aqueous and organic media studied by fluorescence microscopy. Appl. Microbiol. Biotechnol. 64, 695-701. doi: 10.1007/ s00253-003-1508-z 
de Carvalho, C. C. C. R., da Cruz, A. A., Pons, M. N., Pinheiro, H. M., Cabral, J. M., da Fonseca, M. M., et al. (2004b). Mycobacterium sp., Rhodococcus erythropolis, and Pseudomonas putida behavior in the presence of organic solvents. Microsc. Res. Tech. 64, 215-222. doi: 10.1002/jemt.20061

de Carvalho, C. C. C. R., and da Fonseca, M. M. R. (2005). Degradation of hydrocarbons and alcohols at different temperatures and salinities by Rhodococcus erythropolis DCL14. FEMS Microbiol. Ecol. 51, 389-399. doi: 10.1016/j.femsec.2004.09.010

de Carvalho, C. C. C. R., Fatal, V., Alves, S. S., and da Fonseca, M. M. R. (2007). Adaptation of Rhodococcus erythropolis cells to high concentrations of toluene. Appl. Microbiol. Biotechnol. 76, 1423-1430. doi: 10.1007/s00253-007-1103-9

de Carvalho, C. C. C. R., Parreno-Marchante, B., Neumann, G., da Fonseca, M. M. R., and Heipieper, H. J. (2005a). Adaptation of Rhodococcus erythropolis DCL14 to growth on n-alkanes, alcohols and terpenes. Appl. Microbiol. Biotechnol. 67, 383-388. doi: 10.1007/s00253-004-1750-z

de Carvalho, C. C. C. R., Poretti, A., and da Fonseca, M. M. R. (2005b). Cell adaptation to solvent, substrate and product: a successful strategy to overcome product inhibition in a bioconversion system. Appl. Microbiol. Biotechnol. 69, 268-275. doi: 10.1007/s00253-005-1967-5

de Carvalho, C. C. C. R., Wick, L. Y., and Heipieper, H. J. (2009). Cell wall adaptations of planktonic and biofilm Rhodococcus erythropolis cells to growth on C5 to C16 n-alkane hydrocarbons. Appl. Microbiol. Biotechnol. 82, 311-320. doi: 10.1007/s00253-008-1809-3

de Carvalho, C. C. C. R. (2012). Adaptation of Rhodococcus erythropolis cells for growth and bioremediation under extreme conditions. Res. Microbiol. 163, 125-136. doi: 10.1016/j.resmic.2011.11.003

de Carvalho, C. C. C. R., Pons, M.-N., and da Fonseca, M. M. R. (2003). Principal components analysis as a tool to summarise biotransformation data: influence on cells of solvent type and phase ratio. Biocatal. Biotransform. 21, 305-314. doi: 10.1080/10242420310001630146

de Keijzer, J., Mulder, A., de Haas, P. E., de Ru, A. H., Heerkens, E. M., Amaral, L., et al. (2016). Thioridazine alters the cell-envelope permeability of Mycobacterium tuberculosis. J. Proteome Res. 15, 1776-1786. doi: 10.1021/acs. jproteome.5b01037

Deeb, R. A., Chu, K.-H., Shih, T., Linder, S., Suffet, I., Kavanaugh, M. C., et al. (2003). MTBE and other oxygenates: environmental sources, analysis, occurrence, and treatment. Environ. Eng. Sci. 20, 433-447. doi: 10.1089/ 109287503768335922

Deshpande, D., Srivastava, S., Musuka, S., and Gumbo, T. (2016). Thioridazine as chemotherapy for Mycobacterium avium complex diseases. Antimicrob. Agents Chemother. 60, 4652-4658. doi: 10.1128/aac.02985-15

Falkinham, J. O. (2009). Surrounded by mycobacteria: nontuberculous mycobacteria in the human environment. J. Appl. Microbiol. 107, 356-367. doi: 10.1111/j.1365-2672.2009.04161.x

Fernandes, P., Ferreira, B. S., and Cabral, J. M. (2003). Solvent tolerance in bacteria: role of efflux pumps and cross-resistance with antibiotics. Int. J. Antimicrob. Agents 22, 211-216. doi: 10.1016/S0924-8579(03)00209-7

Ferreira, N. L., Maciel, H., Mathis, H., Monot, F., Fayolle-Guichard, F., and Greer, C. W. (2005). Isolation and characterization of a new Mycobacterium austroafricanum strain, IFP 2015, growing on MTBE. Appl. Microbiol. Biotechnol. 70, 358-365. doi: 10.1007/s00253-005-0074-y

Fox, J. H., Hassell, J. E., Siebler, P. H., Arnold, M. R., Lamb, A. K., Smith, D. G., et al. (2017). Preimmunization with a heat-killed preparation of Mycobacterium vaccae enhances fear extinction in the fear-potentiated startle paradigm. Brain Behav. Immun. 66, 70-84. doi: 10.1016/j.bbi.2017.08.014

François, A., Mathis, H., Godefroy, D., Piveteau, P., Fayolle, F., and Monot, F. (2002). Biodegradation of methyl tert-butyl ether and other fuel oxygenates by a new strain, Mycobacterium austroafricanum IFP 2012. Appl. Environ. Microbiol. 68, 2754-2762. doi: 10.1128/aem.68.6.2754-2762.2002

Gonçalves, F. D., and de Carvalho, C. C. C. R. (2016). Phenotypic modifications in Staphylococcus aureus cells exposed to high concentrations of vancomycin and teicoplanin. Front. Microbiol. 7:13. doi: 10.3389/fmicb.2016.00013

Gutiérrez, J. A., Nichols, P., and Couperwhite, I. (1999). Changes in whole cellderived fatty acids induced by benzene and occurrence of the unusual 16:1 $16 \mathrm{c}$ in Rhodococcus sp. 33. FEMS Microbiol. Lett. 176, 213-218. doi: 10.1016/S03781097(99)00238-4

Hachem, R., Raad, I., Rolston, K. V., Whimbey, E., Katz, R., Tarrand, J., et al. (1996). Cutaneous and pulmonary infections caused by
Mycobacterium vaccae. Clin. Infect. Dis. 23, 173-175. doi: 10.1093/clinids/23. 1.173

Heipieper, H. J., and de Bont, J. A. (1994). Adaptation of Pseudomonas putida S12 to ethanol and toluene at the level of the fatty acid composition of membranes. Appl. Environ. Microbiol. 60, 4440-4444.

Heipieper, H. J., Weber, F. J., Sikkema, J., Keweloh, H., and de Bont, J. A. M. (1994). Mechanisms of resistance of whole cells to toxic organic solvents. Trends Biotechnol. 12, 409-415. doi: 10.1016/0167-7799(94)90029-9

Hiatt, M. H., and Pia, J. H. (2004). Screening processed milk for volatile organic compounds using vacuum distillation/gas chromatography/mass spectrometry. Arch. Environ. Contam. Toxicol. 46, 189-196. doi: 10.1007/s00244-003-2308-2

Hiemenz, P. C., and Rajagopalan, R. (1986). Principles of Colloid and Surface Chemistry. Boca Raton, FL: CRC Press.

Hoffmann, C., Leis, A., Niederweis, M., Plitzko, J. M., and Engelhardt, H. (2008). Disclosure of the mycobacterial outer membrane: cryo-electron tomography and vitreous sections reveal the lipid bilayer structure. Proc. Natl. Acad. Sci. U.S.A. 105, 3963-3967. doi: 10.1073/pnas.0709530105

Hsu, W.-H., Kuo, C.-H., Wang, S. S., Lu, C.-Y., Liu, C.-J., Chuah, S.-K., et al. (2014). Acid suppressive agents and risk of Mycobacterium tuberculosis: case-control study. BMC Gastroenterol. 14:91. doi: 10.1186/1471-230x-14-91

Huang, C.-Y., and Hsieh, W.-Y. (2017). Efficacy of Mycobacterium vaccae immunotherapy for patients with tuberculosis: a systematic review and metaanalysis. Hum. Vaccin. Immunother. 13, 1960-1971. doi: 10.1080/21645515. 2017.1335374

Hunter, G. J. (1953). The oxidation of glycerol by mycobacteria. Biochem. J. 55, 320-328. doi: 10.1042/bj0550320

Isken, S., and de Bont, J. A. (1996). Active efflux of toluene in a solvent-resistant bacterium. J. Bacteriol. 178, 6056-6058. doi: 10.1128/jb.178.20.6056-6058. 1996

Jarlier, V., and Nikaido, H. (1990). Permeability barrier to hydrophilic solutes in Mycobacterium chelonei. J. Bacteriol. 172, 1418-1423. doi: 10.1128/jb.172.3. 1418-1423.1990

Johnsen, A. R., Schmidt, S., Hybholt, T. K., Henriksen, S., Jacobsen, C. S., and Andersen, O. (2007). Strong impact on the polycyclic aromatic hydrocarbon (PAH)-degrading community of a PAH-polluted soil but marginal effect on PAH degradation when priming with bioremediated soil dominated by Mycobacteria. Appl. Environ. Microbiol. 73, 1474-1480. doi: 10.1128/aem. 02236-06

Johnson, E. L., Smith, C. A., O’Reilly, K. T., and Hyman, M. R. (2004). Induction of methyl tertiary butyl ether ( MTBE ) - oxidizing activity in Mycobacterium vaccae JOB5 by MTBE. Appl. Environ. Microbiol. 70, 1023-1030. doi: 10.1128/ AEM.70.2.1023-1030.2004

Johnson, J. L., Kamya, R. M., Okwera, A., Loughlin, A. M., Nyole, S., Hom, D. L., et al. (2000). Randomized controlled trial of Mycobacterium vaccae immunotherapy in non-human immunodeficiency virus-infected Ugandan adults with newly diagnosed pulmonary tuberculosis. J. Infect. Dis. 181, 1304-1312. doi: 10.1086/315393

Jonkers, D., Stobberingh, E., and Stockbrügger, R. (1996). Omeprazole inhibis growth of Gram-positive and Gram-negative bacteria including Helicobacter pylori in vitro. J. Antimicrob. Chemother. 37, 145-150. doi: 10.1093/jac/37.1.145

Katoch, V. M. (2004). Infections due to non-tuberculous mycobacteria (NTM). Indian J. Med. Res. 120, 290-304.

Kieser, K. J., Baranowski, C., Chao, M. C., Long, J. E., Sassetti, C. M., Waldor, M. K., et al. (2015). Peptidoglycan synthesis in Mycobacterium tuberculosis is organized into networks with varying drug susceptibility. Proc. Natl. Acad. Sci. U.S.A. 112, 13087-13092. doi: 10.1073/pnas.1514135112

Kobayashi, H., Yamamoto, M., and Aono, R. (1998). Appearance of a stressresponse protein, phage-shock protein A, in Escherichia coli exposed to hydrophobic organic solvents. Microbiology 144, 353-359. doi: 10.1099/ 00221287-144-2-353

Leal, A. J., Rodrigues, E. M., Leal, P. L., Júlio, A. D. L., Fernandes, R. C. R., Borges, A. C., et al. (2017). Changes in the microbial community during bioremediation of gasoline-contaminated soil. Braz. J. Microbiol. 48, 342-351. doi: 10.1016/j. bjm.2016.10.018

Lemos, D. A., Cardoso, S. L., Vieira, P. A., and Cardoso, V. L. (2013). Bioremediation of soil contaminated with biodiesel and glycerin - results of soil microbial adaptation through evidence contaminants removal. Chem. Eng. Trans. 32, 463-468. doi: 10.3303/CET1332078 
Malanovic, N., and Lohner, K. (2016). Gram-positive bacterial cell envelopes: the impact on the activity of antimicrobial peptides. Biochim. Biophys. Acta Biomembr. 1858, 936-946. doi: 10.1016/j.bbamem.2015.11.004

Manzetti, S., and Andersen, O. (2015). A review of emission products from bioethanol and its blends with gasoline. Background for new guidelines for emission control. Fuel 140, 293-301. doi: 10.1016/j.fuel.2014.09.101

Matthews, D. M., and Jenks, S. M. (2013). Ingestion of Mycobacterium vaccae decreases anxiety-related behavior and improves learning in mice. Behav. Process. 96, 27-35. doi: 10.1016/j.beproc.2013.02.007

Murínova, S., and Dercová, K. (2014). Response mechanisms of bacterial degraders to environmental contaminants on the level of cell walls and cytoplasmic membrane. Int. J. Microbiol. 2014:873081. doi: 10.1155/2014/873081

Nelson, D. K., LaPara, T. M., and Novak, P. J. (2010). Effects of ethanol-based fuel contamination: microbial community changes, production of regulated compounds, and methane generation. Environ. Sci. Technol. 44, 4525-4530. doi: $10.1021 /$ es903940q

Niederweis, M. (2008). Nutrient acquisition by mycobacteria. Microbiology 154, 679-692. doi: 10.1099/mic.0.2007/012872-0

Nielsen, L. E., Kadavy, D. R., Rajagopal, S., Drijber, R., and Nickerson, K. W. (2005). Survey of extreme solvent tolerance in gram-positive cocci: membrane fatty acid changes in Staphylococcus haemolyticus grown in toluene. Appl. Environ. Microbiol. 71, 5171-5176. doi: 10.1128/AEM.71.9.5171-5176.2005

Nikaido, H., Kim, S.-H., and Rosenberg, E. Y. (1993). Physical organization of lipids in the cell wall of Mycobacterium chelonae. Mol. Microbiol. 8, 1025-1030. doi: 10.1111/j.1365-2958.1993.tb01647.x

O’Brien, M. E., Anderson, H., Kaukel, E., O’Byrne, K., Pawlicki, M., von Pawel, J., et al. (2004). SRL172 (killed Mycobacterium vaccae) in addition to standard chemotherapy improves quality of life without affecting survival, in patients with advanced non-small-cell lung cancer: phase III results. Ann. Oncol. 15, 906-914. doi: 10.1093/annonc/mdh220

Ohkubo, N., Hashimoto, A. H., and Iwasaki, K. (2009). Biodegradation of methyl tert-butyl ether by Mycobacterium spp. J. Environ. Biotechnol. 9, 113-122.

Pang, H., Li, G., Wan, L., Jiang, Y., Liu, H., Zhao, X., et al. (2015). In vitro drug susceptibility of 40 international reference rapidly growing mycobacteria to 20 antimicrobial agents. Int. J. Clin. Exp. Med. 8, 15423-15431.

Parenti, F. (1986). Structure and mechanism of action of teicoplanin. J. Hosp. Infect. 7, 79-83. doi: 10.1016/0195-6701(86)90011-3

Penna, T. C., Mazzola, P. G., and Silva Martins, A. M. (2001). The efficacy of chemical agents in cleaning and disinfection programs. BMC Infect. Dis. 1:16. doi: 10.1186/1471-2334-1-16

Pinkart, H. C., and White, D. C. (1997). Phospholipid biosynthesis and solvent tolerance in Pseudomonas putida strains. J. Bacteriol. 79, 4219-4226. doi: 10. 1128/jb.179.13.4219-4226.1997

Poger, D., Caron, B., and Mark, A. E. (2014). Effect of methyl-branched fatty acids on the structure of lipid bilayers. J. Phys. Chem. B 118, 13838-13848. doi: 10.1021/jp503910r

Poole, K. (2012). Bacterial stress responses as determinants of antimicrobial resistance. J. Antimicrob. Chemother. 67, 2069-2089. doi: 10.1093/jac/dks196

Ramos, J. L., Duque, E., Gallegos, M.-T., Godoy, P., Ramos-Gonzalez, M. I., Rojas, A., et al. (2002). Mechanisms of solvent tolerance in Gram-negative bacteria. Annu. Rev. Microbiol. 56, 743-768.

Ramos, J. L., Duque, E., Godoy, P., and Segura, A. (1998). Efflux pumps involved in toluene tolerance in Pseudomonas putida DOT-T1E. J. Bacteriol. 180, 3323-3329.

Raut, M. P., Karunakaran, E., Mukherjee, J., Biggs, C. A., and Wright, P. C. (2015). Influence of substrates on the surface characteristics and membrane proteome of Fibrobacter succinogenes S85. PLoS One 10:e0141197. doi: 10.1371/journal. pone.0141197

Rodriguez-Rivera, F. P., Zhou, X., Theriot, J. A., and Bertozzi, C. R. (2017). Visualization of mycobacterial membrane dynamics in live cells. J. Am. Chem. Soc. 139, 3488-3495. doi: 10.1021/jacs.6b12541

Santos, R., de Carvalho, C. C. C. R., Stevenson, A., Grant, I. R., and Hallsworth, J. E. (2015). Extraordinary solute-stress tolerance contributes to the environmental tenacity of mycobacteria. Environ. Microbiol. Rep. 7, 746-764. doi: 10.1111/ 1758-2229.12306

Sarathy, J., Dartois, V., Dick, T., and Gengenbacher, M. (2013). Reduced drug uptake in phenotypically resistant nutrient-starved nonreplicating Mycobacterium tuberculosis. Antimicrob. Agents Chemother. 57, 1648-1653. doi: 10.1128/aac.02202-12
Sikkema, J., de Bont, J. A., and Poolman, B. (1995). Mechanisms of membrane toxicity of hydrocarbons. Microbiol. Rev. 59, 201-222.

Skinner, M. A., Prestidge, R., Yuan, S., Strabala, T. J., and Tan, P. L. (2001). The ability of heat-killed Mycobacterium vaccae to stimulate a cytotoxic T-cell response to an unrelated protein is associated with a 65 kilodalton heat-shock protein. Immunology 102, 225-233. doi: 10.1046/j.1365-2567.2001. 01174.x

Suutari, M., and Laakso, S. (1993). Effect of growth temperature on the fatty acid composition of Mycobacterium phlei. Arch. Microbiol. 159, 119-123. doi: $10.1007 /$ bf00250270

Suzuki, K., Tsuyuguchi, K., Matsumoto, H., Niimi, A., Tanaka, E., and Amitani, R. (2000). Effect of proton pump inhibitor alone or in combination with clarithromycin on mycobacterial growth in human alveolar macrophages. FEMS Microbiol. Lett. 182, 69-72. doi: 10.1111/j.1574-6968.2000.tb08875.x

Tay, S. T., Hemond, H. F., Polz, M. F., Cavanaugh, C. M., Dejesus, I., and Krumholz, L. R. (1998). Two new Mycobacterium strains and their role in toluene degradation in a contaminated stream. Appl. Environ. Microbiol. 64, 1715-1720.

Tsitko, I. V., Zaitsev, G. M., Lobanok, A. G., and Salkinoja-Salonen, M. S. (1999). Effect of aromatic compounds on cellular fatty acid composition of Rhodococcus opacus. Appl. Environ. Microbiol. 65, 853-855.

Tyagi, M., da Fonseca, M. M., and de Carvalho, C. C. C. R. (2011). Bioaugmentation and biostimulation strategies to improve the effectiveness of bioremediation processes. Biodegradation 22, 231-241. doi: 10.1007/s10532-010-9394-4

Unell, M., Kabelitz, N., Jansson, J. K., and Heipieper, H. J. (2007). Adaptation of the psychrotroph Arthrobacter chlorophenolicus A6 to growth temperature and the presence of phenols by changes in the anteiso/iso ratio of branched fatty acids. FEMS Microbiol. Lett. 266, 138-143. doi: 10.1111/j.1574-6968.2006.00502.x

Varjani, S. J., Gnansounou, E., and Pandey, A. (2017). Comprehensive review on toxicity of persistent organic pollutants from petroleum refinery waste and their degradation by microorganisms. Chemosphere 188, 280-291. doi: 10.1016/ j.chemosphere.2017.09.005

Wang, X., and Deshusses, M. A. (2007). Biotreatment of groundwater contaminated with MTBE: interaction of common environmental cocontaminants. Biodegradation 18, 37-50. doi: 10.1007/s10532-005-9034-6

Westwell, M. S., Gerhard, U., and Williams, D. H. (1995). Two conformers of the glycopeptide antibiotic teicoplanin with distinct ligand binding sites. J. Antibiot. 48, 1292-1298. doi: 10.7164/antibiotics.48.1292

WHO. (2010). Guide to Local Production: WHO-Recommended Handrub Formulations. Geneva: WHO.

Willumsen, P. A., and Karlson, U. (1997). Screening of bacteria, isolated from PAH-contaminated soils, for production of biosurfactants and bioemulsifiers. Biodegradation 7, 415-423. doi: 10.1007/BF00056425

Xu, L., Wang, Y., Zheng, X., Gui, X., Tao, L., and Wei, H. (2009). Immunotherapeutical potential of Mycobacterium vaccae on M. tuberculosis infection in mice. Cell. Mol. Immunol. 6, 67-72. doi: 10.1038/cmi.2 009.9

Yang, X.-Y., Chen, Q.-F., Li, Y.-P., and Wu, S.-M. (2011). Mycobacterium vaccae as adjuvant therapy to anti-tuberculosis chemotherapy in never-treated tuberculosis patients: a meta-analysis. PLoS One 6:e23826. doi: 10.1371/journal. pone. 0023826

Yeung, T., and Grinstein, S. (2007). Lipid signaling and the modulation of surface charge during phagocytosis. Immunol. Rev. 219, 17-36.

Zhang, L., Zhang, C., Cheng, Z., Yao, Y., and Chen, J. (2013). Biodegradation of benzene, toluene, ethylbenzene, and o-xylene by the bacterium Mycobacterium cosmeticum byf-4. Chemosphere 90, 1340-1347. doi: 10.1016/j.chemosphere. 2012.06.043

Conflict of Interest Statement: The authors declare that the research was conducted in the absence of any commercial or financial relationships that could be construed as a potential conflict of interest.

Copyright (c) 2018 Pacifico, Fernandes and de Carvalho. This is an open-access article distributed under the terms of the Creative Commons Attribution License (CC BY). The use, distribution or reproduction in other forums is permitted, provided the original author(s) and the copyright owner are credited and that the original publication in this journal is cited, in accordance with accepted academic practice. No use, distribution or reproduction is permitted which does not comply with these terms. 